\title{
Manajemen Pelaksanaan Penerimaan Peserta Didik Baru Sistem Zonasi
}

\author{
Santi Vera Mulyani' ${ }^{1}$ Tobari $^{2}$, dan Houtman ${ }^{3}$ \\ ${ }^{1}$ SMAN 1 Muara Sugihan \\ 2,3 Universitas PGRI Palembang \\ E-mail: sveramulyani@gmail.com
}

\begin{tabular}{l} 
Info Artikel \\
\hline Sejarah Artikel: \\
Diterima: Juli 2020 \\
Disetujui: Agustus 2020 \\
Dipublikasikan: September 2020
\end{tabular}

\section{Kata kunci}

Manajemen, Peserta

Didik Baru, Sistem Zonasi

Keywords:

Management, New

Students, Zoning System

\begin{abstract}
ABSTRAK
Penelitian ini bertujuan untuk mengetahui manajemen pelaksanaan Penerimaan Peserta Didik Baru (PPDB) Sistem Zonasi di SMA Negeri1 Muara Sugihan 2019/ 2020. Data didapat dari triangulasi data secara kualitatif melalui tahapan dokumentasi, observasi dan wawancara. Hasil penelitian menunjukkan manajemen pelaksanaan Penerimaan Peserta Didik Baru (PPDB) Sistem Zonasi di SMAN 1 Muara Sugihan dilaksanakan secara manual dan berurutan dari perencanaan, pengorganisasian, pemotivasian (penggerakan) hingga pengawasan. Perlu kajian ulang terkait ketentuan penerimaan peserta didik baru dari jalur zonasi paling sedikit $90 \%$ dari daya tampung karena tidak semua daerah berada pada kondisi yang sama untuk memenuhi ketentuan itu salah satunya di SMA Negeri 1 Muara Sugihan. Selain itu penting untuk dilakukan promosi dan publikasi baik online maupun offline selain sistem seleksi dalam PPDB. Peneliti merekomendasikan untuk mempertahankan serta meningkatkan kualitas sekolah.
\end{abstract}

\begin{abstract}
This study aims to determine the management of the implementation of the New Student Admission (PPDB) Zoning System in SMA Negeri 1 Muara Sugihan 2019 / 2020. Data obtained from the triangulation of data qualitatively through the stages of documentation, observation and interviews. The results showed the management of the implementation of the New Student Admission (PPDB) Zoning System at SMAN 1 Muara Sugihan carried out manually and sequentially from planning, organizing, motivating (mobilizing) to supervision. It needs to be reviewed in relation to the provision of new student admissions from the zoning route of at least $90 \%$ of the capacity because not all regions are in the same condition to meet the conditions, one of them is in SMA Negeri 1 Muara Sugihan. In addition it is important to do promotions and publications both online and offline besides the selection system in PPDB. Researchers recommend to maintain and improve school quality.
\end{abstract}

(C) 2020 Santi Vera Mulyani, Tobari, Houtman Under The License CC-BY SA 4.0

\section{PENDAHULUAN}

Teknologi terus berkembang dan mengglobal sebagai alat mempermudah kehidupan manusia. Kesadaran akan pendidikan pun semakin meningkat. Salah satu cara yang paling efektif untuk mempersiapkan diri dalam menghadapi globalisasi yaitu dengan meningkatkan kesadaran dan menambah wawasan melalui pendidikan (Mustari \& Rahman, 
2014). Informasi dan komunikasi, peluang kerja serta liberalisasi yang sudah mendunia menimbulkan beragam tantangan perubahan (Primasari, Mulyani \& Dalena, 2018). Demikian halnya dengan perubahan di bidang pendidikan yang tidak terlepas dari peran seluruh warga sekolah dalam koridor manajemen pendidikan. Bahkan setiap organisasi yang juga akan mengalami dan mendapat pengaruh dari adanya perubahan (Nashuddin, 2016; Kristiawan, 2018). Kepemimpinan dalam organisasi sangatlah penting. Houtman, 2017) juga mengulas tentang kepemimpinan. Kepercayaan dan kepatuhan bawahan pada atasan menjadi bukti kekuatan daya pimpin yang dimiliki seseorang dan bahkan menjadi ketangguhan dalam tim. Perubahan dalam penerimaan siswa baru juga memengaruhi dunia pendidikan, terutama dari segi terbukanya kesempatan belajar bagi setiap orang yang tinggal di dekat lokasi sekolah.

Penyelenggaraan pendidikan akan berjalan baik jika ada koordinasi antar berbagai komponen dalam manajemen pendidikan seperti kurikulum, peserta didik, pembiayaan, tenaga pelaksana, dan sarana prasarana mendukung keberhasilan dalam penyelenggaraan lembaga pendidikan (Nasihin \& Sururi, 2017). Manajemen sangat dibutuhkan untuk mengembangkan lembaga pendidikan ke arah yang lebih baik (Nurdyansyah \& Widodo, 2017). Mengutip pendapat (Ahmad, 2016), manajemen sebagai proses untuk menyelesaikan pekerjaan melalui orang lain dengan 4 fungsi manajemen yaitu merencanakan, mengorganisir, menggerakkan dan mengawasi atau mengontrol. Terry juga mengungkapkan bahwa manajemen dilaksanakan untuk kepentingan manusia yang memiliki tujuan utama untuk memberikan keputusan yang lebih baik (Terry, 2014: 210). Demikian halnya dengan manajemen pendidikan.

Manajemen pendidikan yang baik adalah manajemen yang senantiasa menjaga hubungan baik dengan pelanggan baik dari orang tua, alumni dan dunia usaha (Harapan, 2018). Pendidikan sebagai usaha di bidang jasa harus memperhatikan agar selalu terjalin hubungan baik dengan orang tua dan juga alumni salah satunya dengan mempertahankan dan meningkatkan mutu sekolah terlebih dalam rangka PPDB.

Penerimaan Peserta Didik Baru (PPDB) merupakan proses pelayanan dan pencatatan siswa dalam penerimaan peserta didik baru, setelah melalui seleksi masuk siswa/ peserta didik baru dengan persyaratan yang telah ditentukan (Rohiat, 2012). Persyaratan yang ditentukan beberapa tahun belakangan ini adalah mengenai ketentuan sistem zonasi dalam penerimaan peserta didik baru. Sistem zonasi ini dinilai dapat menjadi solusi agar terjadi pemerataan akses pendidikan bagi semua golongan. (Taufiqurokhman 
dan Satispi, 2018) mengemukakan keadilan dan pemerataan dimaksudkan agar jangkauan pelayanan diusahakan seluas mungkin dengan distribusi yang merata dan adil bagi seluruh lapisan masyarakat. Menurut Supriono (Direktur Jenderal Guru dan Tenaga Kependidikan Kemdikbud) seperti dikutip dalam republika.co.id (04 Sep 2018), program zonasi ini bisa mempermudah dalam proses penyelesaian masalah dan peningkatan mutu pendidikan di setiap daerah/ zona. Sehingga setiap daerah akan mendapatkan pendidikan bermutu.

Berdasarkan penelitian yang relevan dengan penelitian ini yaitu penelitian yang dilakukan oleh Iskandar (2011) Manajemen Pelaksanaan Penerimaan Peserta Didik Baru Sistem Zonasi (PPDB): Studi Situs SMK YPE Suwunggalih Kutoarjo Purworejo, ditemukan bahwa manajemen penerimaan peserta didik dilakukan dengan cara promosi dan tidak mengadakan tes masuk yang diawali dengan pembentukan panitia PPDB terlebih dahulu. Sehingga penting sekali untuk diadakan promosi dalam penerimaan peserta didik baru. Seperti yang dikemukakan oleh (Adiwisastra, Irawati dan Purwanti,2018) adanya sistem zonasi diharapkan semua warga yang lokasinya dekat dengan tempat tinggal akan mendapatkan layanan pendidikan sehingga lebih hemat waktu, hemat dalam biaya transportasi, kondisi peserta didik lebih bugar, mengurangi kemacetan hingga terjadi pemerataan pendidikan. Berbagai keuntungan tersebut akan didapat jika setiap sekolah pemerintah di daerah dapat menampung calon peserta didik baru yang berasal dari lingkungan di sekitarnya. (Hoerudin, 2019) juga mengemukakan bahwa sistem zonasi untuk memastikan membawa lingkungan sekolah lebih dekat ke lingkungan keluarga, menghilangkan eksklusivitas dan diskriminasi di sekolah, terutama sekolah umum, membantu menganalisis perhitungan kebutuhan dan distribusi guru.

SMAN 1 Muara Sugihan berlokasi di daerah perairan kabupaten Banyuasin Sumatera Selatan. Pada penerimaan peserta didik sebelumnya mengalami kekurangan peserta didik. Siswa dapat langsung diterima dengan syarat ijasah SMP atau sederajat. Namun demikian lulusannya banyak yang melanjutkan ke perguruan tinggi baik yang negeri maupun yang swasta baik di dalam maupun di luar negeri. Terdorong keinginan untuk mengetahui upaya-upaya yang dilakukan dalam melakukan manajemen penerimaan peserta didik baru, maka penulis tertarik untuk mengkaji manajemen penerimaan peserta didik baru di SMAN 1 Muara Sugihan pada tahun pelajaran 2019/2020. Tujuan penelitian ini yaitu untuk mengetahui manajemen pelaksanaan Penerimaan Peserta Didik Baru sistem zonasi di SMAN 1 Muara Sugihan. 


\section{METODE PENELITIAN}

Penelitian kualitatif ini bertujuan untuk mendeskripsikan manajemen pelaksanaan Penerimaan Peserta Didik Baru Sistem Zonasi di SMAN 1 Muara Sugihan. Adapun metode penelitian kualitatif sebagaimana menurut (Sugiyono, 2018), merupakan metode yang digunakan guna meneliti kondisi objek yang alamiah, peneliti sebagai instrumen kunci, teknik pengumpulan data secara triangulasi (gabungan), analisis data bersifat induksi/kualitatif, dan hasil penelitian lebih menekankan pada makna. Sebagaimana (Arikunto, 2013) menjelaskan bahwa pengumpulan dan perekaman data kualitatif selanjutnya dilakukan dengan cara triangulasi data yang berupa gabungan data observasi (pengamatan), interview (wawancara) dan dokumentasi.

Penelitian kualitatif ini menafsirkan fenomena (gejala) yang terjadi melalui berbagai cara dengan melibatkan berbagai metode yang ada Moloeng, 2012). Sehingga proses disini menjadi kajian penting. Seperti yang ditulis (Muslih, 2004), berbeda dari proses-proses alam yang dapat diprediksi dan dikuasai secara teknis, proses-proses sosial terdiri dari tindakantindakan manusia yang tidak dapat begitu saja diprediksi, apalagi dikuasai secara teknis.

Penelitian kualitatif sebagaimana diutarakan oleh (Sugiyono, 2010) tidak menetapkan penelitiannya berdasarkan variabel-variabel tertentu melainkan meneliti keseluruhan situasi sosial dari aspek tempat (place), pelaku (actor) dan aktivitas (activity) yang saling terkait. Tidak membedakan setiap variabel tetapi setiap variabel saling terkait satu dengan yang lainnya.

Berdasarkan penjelasan tersebut dapat disimpulkan bahwa penelitian kualitatif dilakukan guna mendeskripsikan dan menganalisis objek alamiah dengan instrumen data adalah peneliti sendiri melalui penafsiran terhadap fenomena dengan teknik pengumpulan data gabungan antara observasi, wawancara dan dokumentasi (triangulasi) dengan bermuara pada hasil yang lebih menekankan pada makna.

Fokus penelitian ini adalah mengkaji fenomena yang terjadi di SMAN 1 Muara Sugihan berkaitan dengan manajemen pelaksanaan penerimaan peserta didik baru sistem zonasi sebagai bagian dari manajemen peserta didik dalam manajemen pendidikan. Fenomena tersebut dikaji dengan cara menganalisis penerapan kebijakan sistem zonasi berdasarkan Permendikbud Nomor 51 Tahun 2018 tentang Sistem Zonasi dan implementasi kebijakan Kurikulum 2013 dalam manajemen pelaksanaan penerimaan peserta didik baru sistem zonasi di SMAN 1 Muara Sugihan pada tahun pembelajaran 2019/ 2020 yang telah dilakukan beberapa waktu lalu. 


\section{HASIL PENELITIAN}

1. Manajemen PPDB di SMA Negeri 1 Muara Sugihan

Dilihat dari perencanaan PPDB, sekolah sudah menentukan keadaan sekolah sekarang terkait jumlah rombel (rombongan belajar) dan daya tampung namun belum melakukan survei lingkungan dengan baik hanya berupa survei data siswa dari sekolah asal. Selain itu sekolah sudah mengubah dan menyesuaikan rencana-rencana sebelumnya sehubungan dengan PPDB sistem zonasi namun regulasi yang digunakan belum yang terbaru sekali. Sementara itu dilihat dari pengorganisasian PPDB, sekolah sudah membagi-bagi pekerjaan menjadi tugastugas setiap orang dalam kepanitiaan PPDB dan setiap anggota panitia sudah saling berkolaborasi. Terlihat sekali manajemen PPDB sistem zonasi di SMA Negeri 1 Muara Sugihan menunjukkan adanya pengorganisasian yang dilakukan untuk menghimpun dan menyusun semua sumber yang disyaratkan dalam rencana, terutama sumber daya manusia itu sendiri. Adapun dari segi pemotivasian (Penggerakan PPDB), kepala sekolah sudah menjalin hubungan baik dengan bawahannya pada umumnya dan dengan panitia PPDB pada khususnya. Sedangkan pada segi pengawasan PPDB, sekolah sudah menetapkan ketentuan PPDB dalam bentuk SK dan surat edaran tentang juknis PPDB, kepala sekolah juga sudah memonitor hasil dan membandingkannya dengan ketentuan PPDB. Tidak hanya itu, kepala sekolah juga terus berkoordinasi dengan panitia PPDB selama proses perencanaan, pengorganisasian, pemotivasian dan pengawasan.

\section{Pelaksanaan PPDB di SMA Negeri 1 Muara Sugihan}

Pelaksanaan pendaftaran calon peserta didik baru dilakukan secara manual (luring), PPDB menggunakan sistem seleksi bukan promosi. Adapun seleksi melalui tes tertulis dan wawancara. Seleksi juga untuk menentukan peminatan (jurusan IPA atau IPS). Seleksi PPDB tidak berbeda dengan tahun sebelumnya yang menggunakan sistem rayon. Proses seleksi melibatkan sekolah asal dalam hal koordinasi nilai UN dan rapor secara kolektif dari sekolah zonasi. Pendaftaran dapat dilakukan secara mandiri terutama bagi calon peserta didik yang berasal dari luar zonasi. Tahapan seleksi terdiri atas undangan ke SMP/ MTs, pendaftaran secara kolektif dari SMP/ MTs, seleksi berkas, Tes Potensi Akademik, Tes Wawancara, Pengumuman, dan Daftar ulang.

Gabungan antara nilai UN (25\%), hasil tes potensi akademik (60\%), nilai rapor (15\%) serta zonasi domisili menjadi pertimbangan utama dalam proses seleksi. Materi dalam tes potensi akademik adalah mata pelajaran Bahasa Indonesia, Bahasa Inggris, Matematika dan 
IPA. Ditemukan juga adanya rapat penentuan peserta didik yang diterima. Pengumuman hasil seleksi calon peserta didik baru diketahui dengan cara mendatangi SMA untuk mengetahui pengumuman secara langsung dari panitia PPDB. Ada proses registrasi (daftar ulang) dengan melampirkan berkas untuk keperluan dapodik.

3. Penerimaan Peserta Didik Baru (PPDB) Sistem Zonasi di SMA Negeri 1 Muara Sugihan Berdasarkan Permendikbud Nomor 51 Tahun 2018

Hasil penelitian tentang Penerimaan Peserta Didik Baru (PPDB) Sistem Zonasi di SMA Negeri 1 Muara menunjukkan data jumlah peserta didik yang diterima dari jalur rayon (zonasi) dari tahun 2017/ 2018, 2018/ 2019 dan 2019/ 2020 terus mengalami penurunan dari segi jumlah maupun persentase dari daya tampung yang tersedia yaitu di kisaran $78 \%$ menjadi 73,3\% dan terakhir menjadi 66,11 \% membuktikan bahwa PPDB sistem zonasi berdasarkan Permendikbud Nomor 51 Tahun 2018 tidak dapat diterapkan sepenuhnya di SMAN 1 Muara Sugihan dari segi ketentuan penerimaan peserta didik baru dari jalur zonasi $90 \%$ dari daya tampung.

\section{PEMBAHASAN}

1. Manajemen PPDB di SMA Negeri 1 Muara Sugihan

Dilihat dari perencanaan PPDB, sekolah sudah menentukan keadaan sekolah sekarang terkait jumlah rombel (rombongan belajar) dan daya tampung namun belum melakukan survei lingkungan dengan baik hanya berupa survei data siswa dari sekolah asal. Selain itu sekolah sudah mengubah dan menyesuaikan rencana-rencana sebelumnya sehubungan dengan PPDB sistem zonasi namun regulasi yang digunakan belum yang terbaru sekali. Sementara itu dilihat dari pengorganisasian PPDB, sekolah sudah membagi-bagi pekerjaan menjadi tugas-tugas setiap orang dalam kepanitiaan PPDB dan setiap anggota panitia sudah saling berkolaborasi. Demikian halnya dengan apa yang disampaikan oleh Terry (dalam Kristiawan, dkk. 2019), pengorganisasian dilakukan untuk menghimpun dan menyusun semua sumber yang disyaratkan dalam rencana, terutama sumber daya manusia. Terlihat sekali manajemen PPDB sistem zonasi di SMA Negeri 1 Muara Sugihan menunjukkan adanya pengorganisasian yang dilakukan untuk menghimpun dan menyusun semua sumber yang disyaratkan dalam rencana, terutama sumber daya manusia itu sendiri.

Adapun dari segi pemotivasian (Penggerakan PPDB), kepala sekolah sudah menjalin hubungan baik dengan bawahannya pada umumnya dan dengan panitia PPDB pada khususnya. Sedangkan pada segi pengawasan PPDB, sekolah sudah menetapkan ketentuan 
PPDB dalam bentuk SK dan surat edaran tentang juknis PPDB, kepala sekolah juga sudah memonitor hasil dan membandingkannya dengan ketentuan PPDB. Tidak hanya itu, kepala sekolah juga terus berkoordinasi dengan panitia PPDB selama proses perencanaan, pengorganisasian, pemotivasian dan pengawasan.

Kutipan dari pendapat Ahmad (2016:43) yang mendefinisikan manajemen sebagai suatu proses untuk menyelesaikan suatu pekerjaan melalui orang lain dengan menggerakkan 4 fungsi kegiatan dasar manajemen yaitu merencanakan (merupakan landasan perumusan strategi yang efektif), mengorganisir (bertujuan mencapai usaha yang terkoordinasi), menggerakkan (suatu cara untuk memengaruhi orang lain untuk mencapai tujuan) dan mengawasi atau mengontrol (semua kegiatan untuk memastikan pengoperasian yang cocok dengan perencanaan) juga nampak sekali.

Manajemen dalam PPDB sistem zonasi di SMA Negeri 1 Muara Sugihan tahun pembelajaran 2019/2020 menggambarkan proses untuk menyelesaikan PPDB melalui orang lain dengan menggerakkan keempat fungsi kegiatan dasar manajemen yaitu perencanaan PPDB sistem zonasi, mengorganisir PPDB, menggerakkkan PPDB, dan mengawasi atau mengontrol jalannya PPDB. Uraian tersebut juga sejalan dengan yang diutarakan oleh Robert G. Murdoch dan Joel E. Ross dalam Hadiwijaya (2012: 4) tentang adanya usaha mengelompokkan fungsi manajemen menjadi 4 yaitu Perencanaan (Planning), Pengorganisasian (Organizing), Tindakan/ Pelaksanaaan Tugas (Actuating) dan Pengendalian (Controlling). Sementara itu fungsi-fungsi manajemen menurut George R. Terry antara lain Planning, Organizing, Actuating, Controlling (dalam Rifa'i dan Fadhli, 2013) juga berkorelasi dengan hasil penelitian.

Keterangan (Rohiat,2012), yang memandang manajemen dari sudut pandang adanya pengaturan atau pengelolaan sumberdaya yang dimiliki organisasi atau sumberdaya yang harus ada untuk pencapaian yang telah ditetapkan juga diperlihatkan dengan pengelolaan yang dilakukan kepala sekolah dan jajaran panitia PPDB. The Liang Gie (dalam Prihatin,2014 ) memberikan batasan pengertian pada manajemen sebagai segenap perbuatan yang menggerakkan sekelompok orang atau mengarahkan segala fasilitas dalam suatu usaha kerjasama guna mencapai tujuan tertentu sejalan dengan hasil penelitian. Pelaksanaan PPDB sistem zonasi di SMA Negeri 1 Muara Sugihan menunjukkan adanya tindakan menggerakkan dan mengerahkan sekelompok orang yang dalam hal ini adalah panitia PPDB dan berbagai pihak yang terlibat dalam PPDB. Penggerakan tersebut menggunakan segala fasilitas yang ada melalui kerjasama. 


\section{Pelaksanaan PPDB di SMA Negeri 1 Muara Sugihan}

Berdasarkan fokus penelitian pelaksanaan PPDB di SMA Negeri 1 Muara Sugihan ditemukan bahwa alasan pentingnya pelaksanaan PPDB adalah untuk penjaringan peserta didik dan untuk mengetahui kemampuan awal siswa. PPDB Sistem zonasi tidak berbeda dengan istilah sebelumnya yaitu PSB (Penerimaan Siswa Baru) yang menggunakan sistem rayonisasi. Lokasi tempat pelaksanaan PPDB di SMA Negeri 1 Muara Sugihan dengan sekretariat di ruang TU. Dimulai sejak 29 April 2019 pada tahap persiapan sosialisasi dan publikasi PPDB hingga diakhiri ketika memasuki Masa Pengenalan Lingkungan Sekolah (MPLS) di tahun ajaran baru 15 Juli 2019. Pihak yang berperan penting adalah kepala sekolah, wakil kepala sekolah beserta jajaran panitia PPDB serta staf TU SMA, bahkan pihak sekolah asal juga berperan aktif. PPDB dapat diselesaikan dengan baik melalui kolaborasi antara berbagai pihak baik dari dalam maupun dari luar SMA Negeri 1 Muara Sugihan.

Relevansi hasil penelitian terkait rencana menjadi kegiatan yang merupakan indikasi adanya pelaksanaan dengan yang diungkapkan (Terry, 2014) melalui penyelidikan atas urgensi dilaksanakanannya kegiatan, jenis dan jumlah kegiatan, tempat kegiatan dilaksanakan, jadwal pelaksanaan kegiatan, pihak-pihak yang terlibat, serta cara untuk menyelesaikan kegiatan tersebut. Ada pembentukan panitia PPDB, termuat dalam SK kepanitiaan dan surat edaran juknis. Para informan sudah mempelajari juknis. Tidak ada juknis yang tidak dipahami. Ada pembuatan pengumuman PPDB. Media apa yang digunakan dalam pembuatan berupa surat edaran, sebagian menggunakan media WA. Ada pemasangan/ pengiriman pengumuman PPDB. Ada kontak person (cp) yang dapat dihubungi dalam pengumuman namun tidak ada poster-poster sosialisasi PPDB.

Pelaksanaan pendaftaran calon peserta didik baru dilakukan secara manual (luring), PPDB menggunakan sistem seleksi bukan promosi. Adapun seleksi melalui tes tertulis dan wawancara. Seleksi juga untuk menentukan peminatan (jurusan IPA atau IPS). Seleksi PPDB tidak berbeda dengan tahun sebelumnya yang menggunakan sistem rayon. Proses seleksi melibatkan sekolah asal dalam hal koordinasi nilai UN dan rapor secara kolektif dari sekolah zonasi. Pendaftaran dapat dilakukan secara mandiri terutama bagi calon peserta didik yang berasal dari luar zonasi. Tahapan seleksi terdiri atas undangan ke SMP/ MTs, pendaftaran secara kolektif dari SMP/ MTs, seleksi berkas, Tes Potensi Akademik, Tes Wawancara, Pengumuman, dan Daftar ulang. Gabungan antara nilai UN (25\%), hasil tes potensi akademik $(60 \%)$, nilai rapor (15\%) serta zonasi domisili menjadi pertimbangan utama dalam proses seleksi. Materi dalam tes potensi akademik adalah mata pelajaran Bahasa Indonesia, Bahasa 
Inggris, Matematika dan IPA. Terdapat jadwal kegiatan seleksi PPDB yaitu dari 29 April hingga Masa Pengenalan Lingkungan Sekolah (MPLS) 15 Juli 2019. Ditemukan juga adanya rapat penentuan peserta didik yang diterima. Pengumuman hasil seleksi calon peserta didik baru diketahui dengan cara mendatangi SMA untuk mengetahui pengumuman secara langsung dari panitia PPDB. Ada proses registrasi (daftar ulang) dengan melampirkan berkas untuk keperluan dapodik.

3. Penerimaan Peserta Didik Baru (PPDB) Sistem Zonasi di SMA Negeri 1 Muara Sugihan Berdasarkan Permendikbud Nomor 51 Tahun 2018

Hasil penelitian tentang Penerimaan Peserta Didik Baru (PPDB) Sistem Zonasi di SMA Negeri 1 Muara Sugihan Berdasarkan Permendikbud Nomor 51 Tahun 2018 ditemukan bahwa pelaksanaan pendaftaran PPDB dilakukan mulai bulan Mei 2019. Pengumuman pendaftaran penerimaan calon peserta didik baru dilakukan secara terbuka dan berurutan dari pendaftaran, seleksi, pengumuman penetapan peserta didik baru, daftar ulang, hanya saja untuk pengumuman hasil seleksi hanya ditempel di papan pegumuman SMA tidak diberikan pada sekolah asal. Persyaratan calon peserta didik antara lain tercatat pada tingkat akhir SMP/MTs atau yang sudah lulus di tahun sebelumnya dan berumur tidak lebih dari 21 tahun pada tanggal 15 Juli 2019 dibuktikan dengan fotokopi KK dan akte kelahiran yang dilegalisir, dan berbagai berkas lainnya. Terdapat tanggal pendaftaran PPDB yang disebarkan ke sekolah asal yaitu pada tanggal 14-31 Mei 2019.

Namun demikian tidak ada informasi terkait pembagian 3 jalur pendaftaran sistem zonasi (jalur zonasi, jalur prestasi dan jalur perpindahan tugas orang tua) pada surat edaran PPDB yang disebarkan maupun yang tertempel di papan informasi di SMA Negeri 1 Muara Sugihan. Mayoritas menggunakan jalur zonasi, sebagian jalur perpindahan orang tua dan tidak ada yang menggunakan jalur prestasi. Daya tampung tidak tertera dalam pengumuman pendaftaran seperti dalam surat edaran PPDB yang disebarkan, tidak ada juga dalam informasi yang ditempel di papan pengumuman SMA Negeri 1 Muara Sugihan, hanya berupa informasi yang disampaikan secara berantai melalui pesan singkat, telepon dan tatap muka.Daya tampung mengikuti ketersediaan fasilitas dan aturan dapodik dalam hal rombel yaitu 36 peserta didik per rombel, tersedianya lima (5) rombel berarti daya tampung SMA Negeri 1 Muara Sugihan adalah 180 orang. Tanggal penetapan pengumuman hasil seleksi PPDB yaitu 28 Mei 2019. Pengumuman pendaftaran PPDB diketahui dengan cara mendatangi langsung SMA dan dari surat edaran juknis PPDB yang disebarkan. 
Penetapan peserta didik baru dilakukan berdasarkan hasil rapat panitia PPDB yang dipimpin oleh kepala sekolah dan ditetapkan melalui keputusan kepala sekolah baru pada tahun ajaran baru dirapatkan kembali untuk pelaporan. PPDB tahun 2019 di SMA Negeri 1 Muara Sugihan dilaksanakan dengan mekanisme manual atau luar jaringan (luring). Calon peserta didik baru dari SMP/ MTs berusia tidak lebih dari 21 tahun pada tanggal 15 Juli 2019 dan diminta untuk melampirkan foto kopi KK dan akta kelahiran pada berkas pendaftaran. Memiliki ijasah bagi lulusan tahun sebelumnya, memiliki ijasah sementara bagi peserta didik kelas 9 pada tahun berjalan. Memiliki SHUN bagi lulusan tahun sebelumnya, memiliki ijasah sementara yang memuat nilai UN dari DAKOLUN bagi peserta didik kelas 9 pada tahun berjalan. Jalur zonasi adalah jalur mayoritas tetapi tidak mencapai 90\% dari daya tampung. Tidak ada yang mendaftar melalui jalur prestasi. Jalur perpindahan orang tua lebih dari 5\% dari daya tampung.

Kajian (Wattimena, 2012) tentang kebijakan yang seharusnya dapat menampung dan mengembangkan semua pihak terkait sesuai dengan hasil penelitian. Sebagai contoh dalam hasil penelitian yang menemukan bahwa peserta didik yang diterima dari pendaftaran jalur zonasi tidak mencapai $90 \%$ padahal semua calon peserta didik yang berasal dari wilayah zonasi sudah diterima. Dengan demikian bukan berarti bahwa SMA Negeri 1 Muara Sugihan tidak menjalankan kebijakan regulasi dengan baik. Sekolah sebagai sektor publik telah diungkapkan (Taufiqurokhman, 2016) lengkap dengan kendala-kendala yang sering dihadapi pada sektor publik. Hal ini memiliki relevansi dengan hasil penelitian yang menemukan bahwa figur SMA Negeri 1 Muara Sugihan sebagai sekolah negeri karena ketika membuat program harus diselaraskan dengan undang-undang tidak sepenuhnya benar karena pelaksanaannya disesuaikan dengan kondisi yang ada.

Hasil penelitian yang menunjukkan bahwa sekolah dapat melakukan perubahan sekaligus beradaptasi dengan situasi lingkungan serta regulasi yang baru tentang PPDB zonasi merupakan bentuk inovasi juga dan relevan dengan pendapat (Hakim, 2015). Inovasi yang memanfaatkan keterampilan-keterampilan dan sumber-sumber daya untuk mengembangkan pengoperasian baru sehingga sekolah lebih baik dalam bereaksi terhadap kebutuhankebutuhan pelanggan mereka yaitu masyarakat dan calon peserta didik baru. Hasil penelitian juga sejalan dengan pendapat Luthans (dalam Priyono, 2010). Kepala sekolah sebagai pemimpin harus terus menerus berupaya mengembangkan kapasitas dan kemampuan sumber daya manusianya sejalan dengan berbagai perubahan aturan main dan persaingan yang terjadi 
secara cepat. Muncul kebutuhan akan kepemimpinan baru dalam style dan skill untuk menghadapi perubahan lingkungan yang berlangsung semakin cepat.

Penetapan zonasi sudah dilakukan dengan prinsip mendekatkan domisili peserta didik dengan sekolah. Seleksi calon peserta didik baru kelas 10 (sepuluh) SMA menggunakan jalur zonasi dan jalur perpindahan tugas orang tua/wali. Peserta didik melakukan daftar ulang setelah diterima. Pelaksanaan PPDB tidak dipungut biaya. Sekolah melaporkan pelaksanaan PPDB ke dinas pendidikan provinsi secara manual dan online. (Imron, 2012) mengemukakan cara Penerimaan Peserta Didik Baru juga sama dengan hasil penelitian ini.

Hasil penemuan membuktikan bahwa sebetulnya ada dua macam cara yaitu melalui sistem promosi dan seleksi dalam PPDB. Namun PPDB di SMA Negeri 1 Muara Sugihan menggunakan sistem seleksi. (Prihatin, 2014) yang menyebutkan prosedur pelaksanaan PPDB memiliki kesamaan dengan hasil penelitian mulai dari pembentukan panitia pendaftaran hingga daftar ulang. Pendapat (Badrudin, 2014) senada dengan hasil penelitian yang mengulas seleksi peserta didik sebagai kegiatan pemilihan calon peserta didik untuk menentukan diterima atau tidaknya calon peserta didik di SMA Negeri 1 Muara Sugihan berdasarkan ketentuan yang berlaku sehingga diterima atau tidaknya calon peserta didik tidak dapat langsung diketahui dikarenakan harus menunggu hasil dari proses seleksi.

Hasil penelitian yang menunjukkan data jumlah peserta didik yang diterima dari jalur rayon (zonasi) dari tahun 2017/ 2018, 2018/ 2019 dan 2019/ 2020 terus mengalami penurunan dari segi jumlah maupun persentase dari daya tampung yang tersedia yaitu di kisaran $78 \%$ menjadi 73,3 \% dan terakhir menjadi 66,11 \% membuktikan bahwa PPDB sistem zonasi berdasarkan Permendikbud Nomor 51 Tahun 2018 tidak dapat diterapkan sepenuhnya di SMAN 1 Muara Sugihan dari segi ketentuan penerimaan peserta didik baru dari jalur zonasi 90\% dari daya tampung. Penyebaran informasi PPDB dinilai kurang cepat dilakukan bahkan tidak ada sistem promosi. Pengumuman kelulusan seleksi yang hanya ditempel di papan pengumuman di SMAN 1 Muara Sugihan kurang mewakili unsur keterbukaan. Namun demikian keseluruhan proses PPDB sistem zonasi di SMAN 1 Muara Sugihan secara prosedural dan faktual sudah memudahkan masyarakat di lingkungan sekolah untuk melanjutkan pendidikan. Fakta temuan yang menunjukkan bahwa meskipun persentase dari pendaftaran jalur zonasi tidak mencapai $90 \%$ dari daya tampung karena hanya 66, $11 \%$ bukan berarti SMA Negeri 1 belum dapat melaksanakan regulasi PPDB sistem zonasi dengan baik berdasarkan Permendikbud Nomor 51 Tahun 2018. Hal ini terlihat dari 100\% calon peserta didik dari pendaftaran jalur zonasi yang mendaftar sudah diterima. 


\section{SIMPULAN}

Berdasarkan penelitian yang telah dilakukan peneliti, maka berikut beberapa hal yang dapat peneliti simpulkan. Manajemen pelaksanaan PPDB sistem Zonasi di SMAN 1 Muara Sugihan dengan 4 fungsi manajemen yaitu perencanaan, pengorganisasian, pemotivasian (atau penggerakan) dan pengawasan dilakukan secara berkesinambungan. PPDB sistem zonasi berdasarkan Permendikbud Nomor 51 Tahun 2018 tidak dapat diterapkan sepenuhnya di SMAN 1 Muara Sugihan dari segi ketentuan penerimaan peserta didik baru dari jalur zonasi $90 \%$ dari daya tampung karena hanya $66,11 \%$ dari dari daya tampung meskipun seluruh peserta didik yang mendaftar dari jalur zonasi sudah diterima $100 \%$. Peserta didik yang berasal dari zonasi SMAN 1 Muara Sugihan dapat bersekolah di sekolah tersebut sehingga sudah ada pemerataan seperti yang diharapkan pemerintah. Adanya sekolah baru yaitu SMA Negeri 2 Muara Sugihan sejak tahun 2016 dan adanya pembagian zonasi sekolah asal juga menjadi salah satu pencetus menurunnya jumlah peserta didik baru yang diterima di SMAN 1 Muara Sugihan. Namun di sisi lain adanya sekolah baru tersebut juga berdampak pada pemerataan pendidikan karena warga yang bermukim di sekitar sekolah negeri dapat ditampung, baik di SMA Negeri 1 Muara Sugihan maupun SMA Negeri 2 Muara Sugihan. Pengurangan persentase pencapaian dari $90 \%$ dari daya tampung menjadi $50 \%$ dari daya tampung misalnya bisa dijadikan salah satu solusi ketentuan baru terkait regulasi PPDB di kemudian hari mengingat setiap daerah atau setiap zona memiliki karakteristik dan permasalahan sendiri yang tidak bisa dipecahkan secara merata yang tentunya tidak melenceng dari prinsip zonasi yang hakiki yaitu berdasarkan zonanya. Perlunya dibuat publikasi pemberitahuan PPDB dalam bentuk poster maupun pemberitahuan secara online yang juga dapat memanfaatkan media jejaring sosial. Peneliti merekomendasikan untuk mempertahankan serta meningkatkan kualitas sekolah. Adanya sekolah negeri baru sebaiknya disikapi dengan peningkatan mutu dan promosi agar terjadi peningkatan jumlah masyarakat yang mendaftarkan kembali anaknya ke SMAN 1 Muara Sugihan karena sudah membuktikan kualitas sekolah tersebut. Seleksi sangat diperlukan untuk menentukan mutu melalui input PPDB, namun demikian strategi promosi juga masih diperlukan guna keterlaksanaan bidang humas sekaligus bidang kesiswaan dalam mewujudkan pendidikan yang merata bagi setiap golongan. Semua warga sekolah sebaiknya bersikap kritis, adaptif dan inovatif sehingga informasi mengenai regulasi terbaru dapat terus diperbaharui, tidak ketinggalan informasi sekaligus tidak ketinggalan zaman. 


\section{REFERENSI}

Adiwisastra, J., Irawati, I. dan Purwanti, D. (2018). Efektivitas Kebijakan Penerimaan Peserta Didik Baru Sistem Zonasi Bagi Siswa Rawan Melanjutkan Pendidikan. Jurnal Dinamika, 5(4), 1-7.

Ahmad, S. (2016). Ketahanmalangan Kepemimpinan Kepala Sekolah: Salah Satu Faktor Penentu Keberhasilan Kepala Sekolah. Yogyakarta: Deepublish.

Akbar, R. A., \& Tobari, T. (2017). Pengembangan Sumber Daya Manusia Sebagai Salah Satu Faktor Penentu Dalam Meningkatkan Mutu Pendidikan. Jurnal Dosen Universitas PGRI Palembang.

Arikunto, S. (2013). Prosedur Penelitian Suatu Pendekatan Praktek. Jakarta: Rineka Cipta.

Badrudin. (2014). Manajemen Peserta Didik. Jakarta: Indeks.

Hadiwijaya, Y. (2012). Administrasi Pendidikan. Medan: Perdana Publishing.

Hakim, A. (2015). Pengelolaan Perubahan Berbasis Nilai-nilai Islam. Semarang: EF Press Digimedia.

Harapan, E. (2018). Pembiayaan Pendidikan. Palembang: Noer Fikri.

Hoerudin, C. W. (2019). Implementation of Admission Policy for New Student With Zonation Systems in Indonesia. International Journal of Humanities and Social Sciences, 8(5), 17-23.

Houtman, H. (2017). Digitalisasi Pembelajaran dan Pembentukan Karakter Siswa Berbasis Kearifan Lokal. WAHANA DIDAKTIKA, 15(2), 79-98.

Imron, A. (2012). Manajamen Peserta Didik Berbasis Sekolah. Jakarta: Bumi Aksara.

Iskandar, P. (2011). Pengelolaan Penerimaan Peserta Didik Baru (PPDB)(Studi Situs SMK YPE Sawunggalih Kutoarjo Purworejo)(Doctoral dissertation, Universitas Muhammadiyah Surakarta).

Kristiawan, M. dkk. (2018). Inovasi Pendidikan. Ponorogo: Wade

Kristiawan, M. dkk. (2019). Supervisi Pendidikan. Bandung: Alfabeta.

Moloeng, L. J. (2012). Metodologi Penelitian Kualitatif. Bandung: PT. Remaja Rosdakarya.

Muslih, M. (2004). Filsafat Ilmu: Kajian atas Asumsi Dasar, Paradigma, dan Kerangka Teori Ilmu Pengetahuan. Yogyakarta: Belukar.

Mustari, M. dan Rahman, M.T., (2014). Manajemen Pendidikan: Jakarta: RajaGrafindo.

Nashuddin. (2016). Manajemen dan Kepemimpinan dalam Pelayanan Publik. Mataram: Sanabil Publishing.

Nasihin, S. dan Sururi. (2017). "Manajemen Peserta Didik" dalam Tim Dosen Administrasi Pendidikan Universitas Pendidikan Indonesia. Manajemen Pendidikan. Bandung: Alfabeta.

Nurdyansyah dan Widodo, A. (2017). Manajemen Sekolah Berbasis ICT. Sidoarjo: Nizamia. 
Peraturan Menteri Pendidikan dan Kebudayaan Republik Indonesia (Permendikbud) Nomor 51 Tahun 2018 tentang Penerimaan Peserta Didik Baru pada Taman Kanak-Kanak, Sekolah Dasar, Sekolah Menengah Pertama, Sekolah Menengah Atas, Sekolah Menengah Kejuruan, atau Bentuk Lain yang Sederajat .

Prihatin, E. (2014). Manajemen Peserta Didik. Bandung: Alfabeta.

Primasari, D. A. G, Mulyani, S. V., \& Dalena, R. (2018). English Master Urgency and English Learning Method as Increasing Efforts of Teachers' Profesionalism. In Preceeding The 2nd International ASEAN-English Language Teaching Conference UIN Raden Fatah Palembang.

Priyono. (2010). Manajemen Sumber Daya Manusia. Sidoarjo: Zifatama.

Republika.co.id. (2018, September 4). Kemdikbud Rancang Program Zonasi yang $\begin{array}{lllll}\text { Terintegrasi. } & \text { dipetik Juli 2019, dari, }\end{array}$ https://www.republika.co.id/berita/pendidikan/eduaction/18/09/04/peil3w335kemendikbud-rancang-program-zonasi-yang-terintegrasi

Rifa'i, M. dan Fadhli, M. (2013). Manajemen Organisasi. Bandung: Citapustaka Media Perintis.

Rohiat. (2012). Manajemen Sekolah: Teori Dasar dan Praktik. Bandung: Refika Aditama.

Sugiyono. (2010). Memahami Penelitian Kualitatif. Bandung: Alfabeta.

Sugiyono. (2018). Metode Penelitian Kualitatif. Bandung: Alfabeta.

Sukmadinata, N. S. (2009). Metode Penelitian Pendidikan. Bandung: Remaja Rosdakarya.

Taufiqurokhman dan Satispi, E. (2018). Teori Perkembangan Manajemen Pelayanan Publik. Tangerang: UMJ Press.

Terry, G. R. dan Rue, L.W. (2013). Dasar-Dasar Manajemen. Cetakan keempat belas. Diterjemahkan oleh: G.A. Ticoalu. Jakarta: Bumi Aksara.

Terry, G.R., (2014). Prinsip-Prinsip Manajemen. Cetakan ketiga belas. Diterjemahkan oleh: J. Smith D.F.M. Jakarta: Bumi Aksara.

Wattimena, R.A.A. (2012). Menjadi Pemimpin Sejati: Sebuah Refleksi Lintas Ilmu. Jakarta: Evolitera. 